\title{
Secure Navigation for the Blind People by Using RFID System
}

\author{
K. Sri Hari Rao ${ }^{1}$, K. Jyothi ${ }^{2}$, Shaik.Mahamood ${ }^{3}$ \\ Professor\& Head, ECE, NRIIT, Guntur, India ${ }^{1}$ \\ Assoc. Professor, ECE, NRIIT, Guntur, India ${ }^{2}$ \\ M.Tech Scholar, ECE, NRIIT, Guntur, India ${ }^{3}$
}

\begin{abstract}
Safety navigation for the Blind people by using RFID system. IN this Paper RFID system plays main role, RFID (Radio Frequency Identification) providing Bus information to the particular Blind person. So many Papers available for the Blind people but this Paper providing information about the Bus in particular Distance. For example: GPS satellites revolving around the earth, which gives continuous updates on where we are and where we are heading. There will be GPS receivers installed or with a person which will receive signals from the satellite and helps the user to navigate to their desired location. This Paper providing stick to the blind people for obstacle detection and water detection with alarm. Limitation of this Paper is Blind person must come to the nearest location. But RFID system helps to the Blind people is a technology that use wireless radio frequency Transmission to identify the specific object, item or person.
\end{abstract}

Keywords: RFID, GPS, Barcode System analyzer.

\section{INTRODUCTION}

If we want to go to a function at a not so known place and we don't know anything about that place like culture, language etc. what we would do, it would be extremely difficult to reach our desired destination. This is a problem faced by all of us regularly, most of the cases we lose our way which would lead to loss of precious time, energy and money. For most of us, who are normal and healthy at least can reach the destination somehow but for some unfortunates like the blind people finding a location becomes an extremely tedious process. They will be in need of continuous help and companionship till they reach their desired. The blind man as shown in the below figure 1

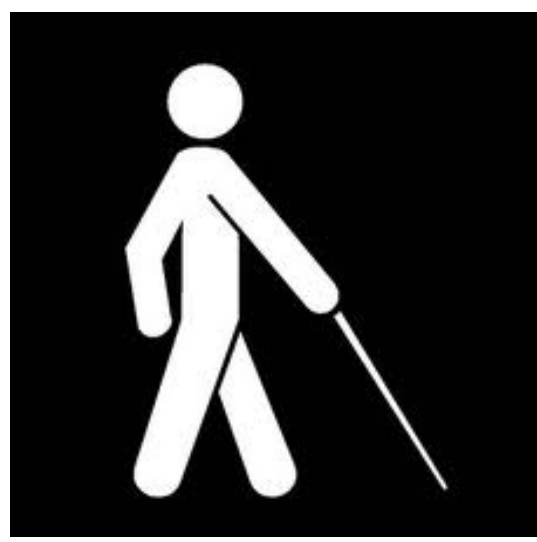

Fig1.Blind Man

RFID is very useful Technology for Blind man to identify the things like Buses, Trains, Railway Station and virtually anything we can think about. We can embed the RFID reader in Blind man stick and put the RFID tags on other things to identify them for the blind man and blow a siren or a prerecorded voice for each item which has RFID tag on it and is in the database of RFID reader of the blind man's stick.
The blind in travelling from one place to another. In order to get transportation independently, the blind use auditory touched clues like walking stick or white cane. The limitation of the walking stick is that a blind person must come into close proximity with their surroundings to determine the location of an obstacle.

An antenna on the tip of a blind person's cane activates each RFID chip it passes over, and the chip responds by radioing its unique tag number to a smart phone the person carries. That phone comes equipped with a database of navigational information that maps the tag numbers to locations throughout the town. The person then receives specific information about position and surroundings through a Bluetooth headset linked to the phone. It can either be a beep or bop that keeps you on the path, or if you have a traffic light, it gives you the information about when to walk. The chipped path stretches for 2 kilometers in one direction, so users cannot yet choose alternate routes. But as the network grows, it will cue people to optional turns and could even guide them to a programmed destination. Because the smart phone's internal map updates itself from a central database, operators can change the information to identify unexpected obstacles like construction. Radio-frequency identification (RFID) is an automatic identification method, relying on storing and remotely retrieving data using devices called RFID tags or transponders. The technology requires some extent of cooperation of an RFID reader and an RFID tag. An RFID tag is an object that can be applied to or incorporated into a product, animal, or person for the purpose of identification and tracking using radio waves. Some tags can be read from several meters away and beyond the line of sight of the reader.

To overcome all this problems there are using Bus Detection Device for the Blind people by using RFID 
INTERNATIONAL JOURNAL OF INNOVATIVE RESEARCH IN ELECTRICAL, ELECTRONICS, INSTRUMENTATION AND CONTROL ENGINEERING Vol. 3, Issue 12, December 2015

application. RFID stands for Radio-Frequency Identification. The acronym refers to small electronic devices that consist of a small chip and an antenna. The chip typically is capable of carrying 2,000 bytes of data or less.

The RFID device serves the same purpose as a bar code or a magnetic strip on the back of a credit card or ATM card; it provides a unique identifier for that object. And, just as a bar code or magnetic strip must be scanned to get the information, the RFID device must be scanned to retrieve the identifying information.

\section{RFID Works Better Than Barcodes}

A significant advantage of RFID devices over the others mentioned above is that the RFID device does not need to be positioned precisely relative to the canner. We're all familiar with the difficulty that store checkout clerks sometimes have in making sure that a barcode can be read. And obviously, credit cards and ATM cards must be swiped through a special reader.

In contrast, RFID devices will work within a few feet (up to 20 feet for high-frequency devices) of the scanner. For example, you could just put all of your groceries or purchases in a bag, and set the bag on the scanner. It would be able to query all of the RFID devices and total your purchase immediately. (Read a more detailed article on RFID compared to barcodes.)

RFID technology has been available for more than fifty years. It has only been recently that the ability to manufacture the RFID devices has fallen to the point where they can be used as a "throwaway" inventory or control device. Alien Technologies recently sold 500 million RFID tags to Gillette at a cost of about ten cents per tag.

One reason that it has taken so long for RFID to come into common use is the lack of standards in the industry. Most companies invested in RFID technology only use the tags to track items within their control; many of the benefits of RFID come when items are tracked from company to company or from country to country.

\section{Common Problems with RFID}

Some common problems with RFID are reader collision and tag collision. Reader collision occurs when the signals from two or more readers overlap. The tag is unable to respond to simultaneous queries. Systems must be carefully set up to avoid this problem. Tag collision occurs when many tags are present in a small area; but since the read time is very fast, it is easier for vendors to develop systems that ensure that tags respond one at a time.

RFID System consists of four basic components:

1) Reader (also called interrogator) comprising of antenna, Transceiver and decoder.

2) RFID tag (also called transponder) which consists of an Integrated circuit (IC) and small antenna.

3) Middleware (also called host).

4) Database for storing product information.

Figure 2 above shows the principles of operation of RFID Systems. A Reader functions as a data capture device which interrogates the tag and retrieve the data from all tags in the Receiving area.

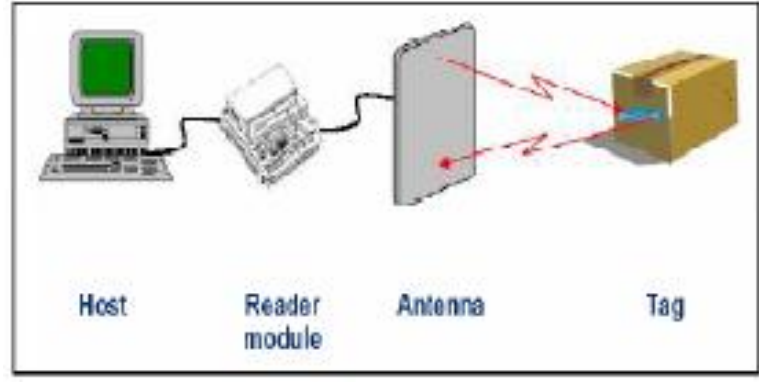

Fig2: Principles of Operation RFID Systems

The area of ejection depends on the antenna used. The detected tags give a response back to the reader. The information is getting from unique Electronic Product Code.

(EPC) Code as programmed in the tag. Then, the reader sends the data to the host. At host the appropriate software are used to support reader in order to extract unique information from the read data and communicate with external databases.

RFID devices that are intended to be implanted inside a living body (like an animal or human being) have special requirements. They need to be encased in a special kind of casing that will not irritate or react with the living tissues that they are inserted into. The casing must also be transparent to the scanning radio-frequency beam that activates the chip. Some RFID vendors have created biocompatible glass for use in these applications.

One potential problem with being placed within a living organism is that the tiny RFID device may move around under the skin. This can be avoided by using special materials that actually let the surrounding tissue grow up to the casing and bond with it.

Because the radio-frequency waves that activate the microchip containing the identification number are only useful within a few feet (or less), the RFID chip is typically inserted very close to the surface of the skin.

The placement of the device is usually done with a hypodermic-type needle. This method of insertion also dictates the shape and size of the device; implantable RFID devices are typically the size and diameter of a grain of rice. For dogs, the device is usually implanted between the shoulder blades.

RFID tags have been placed inside cows; some discussion of having all cows implanted with RFID devices has resulted from the recent scare with mad cow disease. Dog owners have used RFID tags to identify their pets rather than tattoos (the more traditional method)

RFID tags, like the VeriChip tag, can also be implanted inside human beings. See Chip RFID Tag Patient Implant Badges Now FDA Approved for more information.

Add to the information written on a printed barcode. RFID tags, however, can be read/write devices; the RFID reader can communicate with the tag, and alter as much of the Information as the tag design will allow.

- RFID tags are typically more expensive than barcodes, in some cases, much more so.

RFID Application for the Blind People RFID (Radio Frequency Identification) providing Bus information to the particular Blind person. So many Papers available for the 
INTERNATIONAL JOURNAL OF INNOVATIVE RESEARCH IN ELECTRICAL, ELECTRONICS, INSTRUMENTATION AND CONTROL ENGINEERING Vol. 3, Issue 12, December 2015

Table 1: RFID Tag Attributes

\begin{tabular}{|c|c|c|}
\hline Characteristics & $\begin{array}{ll}\text { Passive } & \text { RFID } \\
\text { Tags } & \end{array}$ & $\begin{array}{ll}\text { Active } & \text { RFID } \\
\text { Tags } & \end{array}$ \\
\hline $\begin{array}{l}\text { Power Source } \\
\text { (Battery) }\end{array}$ & $\begin{array}{l}\text { No internal } \\
\text { Power } \\
\text { (Energy } \\
\text { transferred from } \\
\text { the reader) }\end{array}$ & $\begin{array}{l}\text { Internal to the } \\
\text { tags }\end{array}$ \\
\hline Cost & Less Expensive & More expensive \\
\hline Size & $\begin{array}{l}\text { Tag is physically } \\
\text { smaller }\end{array}$ & $\begin{array}{l}\text { Tag is much } \\
\text { larger }\end{array}$ \\
\hline $\begin{array}{l}\text { Coverage } \\
\text { Area }\end{array}$ & Short distance & Long distance \\
\hline $\begin{array}{l}\text { Availability } \\
\text { of tags }\end{array}$ & $\begin{array}{l}\text { Unlimited } \\
\text { operational life } \\
\text { time }\end{array}$ & $\begin{array}{l}\text { Limited } \\
\text { operational life } \\
\text { time }\end{array}$ \\
\hline $\begin{array}{l}\text { Capacity } \\
\text { of memory }\end{array}$ & $\begin{array}{l}\text { Limited memory } \\
\text { (Up to } 16 \mathrm{Kbits} \text { ) }\end{array}$ & $\begin{array}{l}\text { More large } \\
\text { memory }(128 \mathrm{~Kb})\end{array}$ \\
\hline $\begin{array}{l}\text { Availability } \\
\text { of } \\
\text { enhancement }\end{array}$ & $\begin{array}{l}\text { No enhancement } \\
\text { applied }\end{array}$ & $\begin{array}{l}\text { Contain sensor, } \\
\text { GPS, satellite } \\
\text { links or others }\end{array}$ \\
\hline
\end{tabular}

Blind people but this Paper providing information about the Bus in particular Distance. For example: 1.GPS satellites revolving around the earth, which gives continuous updates on where we are and where we are heading. There will be GPS receivers installed or with a person which will receive signals from the satellite and helps the user to navigate to their desired location.

2. This Paper providing stick to the blind people for bstacle detection and water detection with alarm. Limitation of this Paper is Blind person must come to the nearest location. But RFID system helps to the Blind people is a technology that use wireless radio frequency transmission to identify the specific object, item or person.

\section{BACKGROUND TO THE RESEARCH}

In world so many Blind people's facing problem's in roads for traveling one place to another place. Blind people do not known about particular Bus services name and number. But This Paper providing particular information to the Blind people By using RFID system.

In RFID system having the reader, tag or sensor. Reader can find the Bus route, Bus destination and bus number will be sent or tag is used in bus for sending the information. Reader is attached to the computer and by using audio system particular information can be given to the Blind people. Distance of the Bus can be depends upon the antenna efficiency, Bandwidth, gain etc.

RFID Characteristic Test: The Paper is planned using Ultra-High Frequency (UHF) tag and antenna since the application needs to have a detection range of 1 to 3 meters.

\section{1) Polarization (Antenna Characteristic Test)}

Polarization is very important to the RFID implementer. The best power transfer between two antennas takes place when their polarizations are aligned.
There are different types of antenna design such as linearpolarized antennas and circular-polarized antennas. For this Paper, the UHF antenna is going to determine the type of polarized antennas.

\section{2) Tag Performance (Tag Characteristic Test)}

From the book RFID Implementation, tag performance is referred to how far from the reader the tag can be read..However several other performance factors need to be considered. The appropriate tests are Going to undertake to determine the performance of the tag.

\section{B. Database Development}

Database system is the part to produce the system requirement and objective of the Paper. The database consists of the RFID number, bus route, origin and destination.

Table2: Data Base Development Table

\begin{tabular}{|c|c|c|c|c|}
\hline $\begin{array}{l}\text { Frequen } \\
\text { cy }\end{array}$ & LHF & $\mathrm{HF}$ & UHF & $\begin{array}{l}\text { Micro } \\
\text { wave }\end{array}$ \\
\hline $\begin{array}{l}\text { Range } \\
\{\mathrm{Hz})\end{array}$ & $9-125 \mathrm{~K}$ & $\begin{array}{l}13.56 \\
M\end{array}$ & $\begin{array}{l}300- \\
1200 \mathrm{M}\end{array}$ & $\begin{array}{l}2.45- \\
5.8 \mathrm{~GB}\end{array}$ \\
\hline $\begin{array}{l}\text { Read } \\
\text { Range }\end{array}$ & $<0.5 \mathrm{Mts}$ & $\begin{array}{l}1 \\
\text { metre }\end{array}$ & $100 \mathrm{mts}$ & $10 \mathrm{mts}$ \\
\hline $\begin{array}{l}\text { Power } \\
\text { Source }\end{array}$ & $\begin{array}{l}\text { Passive } \\
\text { Tags }\end{array}$ & $\begin{array}{l}\text { Passiv } \\
\text { e Tags }\end{array}$ & $\begin{array}{l}\text { Both } \\
\text { Tags }\end{array}$ & $\begin{array}{l}\text { Both } \\
\text { Tags }\end{array}$ \\
\hline $\begin{array}{l}\text { Current } \\
\text { Applicat } \\
\text { ion }\end{array}$ & $\begin{array}{l}\text { Access } \\
\text { Control } \\
\text { and } \\
\text { Minimal } \\
\text { Tracking }\end{array}$ & $\begin{array}{l}\text { Item } \\
\text { level } \\
\text { trackin } \\
\text {-g and } \\
\text { smart } \\
\text { cards }\end{array}$ & $\begin{array}{l}\text { Baggage } \\
\text { handling }\end{array}$ & $\begin{array}{l}\text { Asset } \\
\text { trackin } \\
\mathrm{g} \text { and } \\
\text { collecti } \\
\text { on }\end{array}$ \\
\hline General & $\begin{array}{l}\text { Largest } \\
\text { current } \\
\text { install } \\
\text { base }\end{array}$ & $\begin{array}{l}\text { Wide } \\
\text { option } \\
\text { due to } \\
\text { smart } \\
\text { phone } \\
\text { adopti- } \\
\text { on }\end{array}$ & & \\
\hline $\begin{array}{l}\text { Energy } \\
\text { efficienc } \\
\text { y }\end{array}$ & \multicolumn{4}{|c|}{ 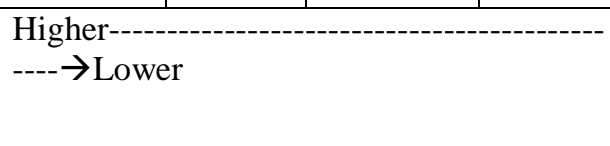 } \\
\hline
\end{tabular}

\section{CONCLUSION}

Safety Navigation for the Blind people by using RFID. This project can be developed for the Blind people to travel easily in buses. By using RFID so many projects developed. Hopefully the project will help blind people. Finally, RFID technology is very interesting area and can be widely expand in the future.

\section{REFERENCES}

[1] Lanigan PE, Paulos AM, Williams AW, Narasimhan P. Trinetra: Assistive Technologies for the Blind. Carnegie Mellon University Pittsburgh, PA 15213, May 1, 2006.

[2] Lahiri S. RFID Sourcebook. 2006.

[3] Batarseh DT, Burcham TN, McFadyen GM. An Ultrasonic Ranging System for the Blind. Agricultural and Biological Engineering Mississippi State University, 1997, IEEE. 
[4] Uddin MS, Shioyama T. Measurement of the Length of Pedestrian Crossings-A Navigational Aid for Blind People. Intelligent Transportation Systems Conference, Oct 36, 2004.

[5] Ersin BAL. An Rfid Application for The Disabled: Path Finder. Petrol Ofisi A.S.

[6] Buniyamin N, Ismail I, Mohamad Z. RFID Tagging In Monitoring and Control of Oil Palm Breeding and Traceability of Seeds. Universiti Teknologi MARA, Shah Alam, Malaysia, 2005

[7] Why RFID [http://www.databrokers.net/body_why_rfid.html ]

[8] RFID Nineteen Eighty-four, Spychips.com.[http://www.spychips .com/what-is-rfid.html ]

[9] A RFID Device to Improve Shelf Replenishment Efficiency, José Wagner de O., Bezerra Edmilson, C. Moreira Marcelo F. de Sousa, Instituto Atlântico (IA), CEP 60822-780 -Fortaleza - CE - Brazil

[10] From Wikipedia, the free encyclopedia, 26 April 2008.[http://en.wikipedia.org/wiki/RFID ]

[11] The RF in RFID, Danial M. Dobkin, 2007.

\section{BIOGRAPHIES}

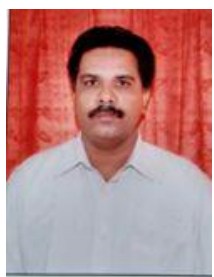

K. Sri Hari Rao is a professor and Head of ECE dept in NRI Institute of Technology, Guntur. He was awarded a $\mathrm{PhD}$ degree from Andhra University in 2013.His Areas of Research includes Radar systems.

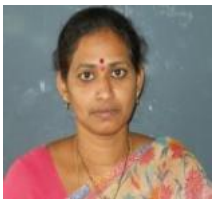

K. Jyothi is an associate professor in NRI Institute of Technology, Guntur. She was awarded M.Tech Degree from Nagarjuna University.

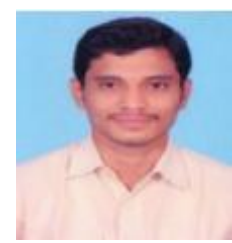

Shaik.Mahamood is M.Tech Scholar in Department of Electronics and Communications in NRI Institute of Technology, Guntur. He completed His B.Tech in 2012 from NRI Institute of Technology, Guntur. 